Article

\title{
Optimising Tropical Fruit Juice Quality Using Thermosonication-Assisted Extraction via Blocked Face-Centered Composite Design
}

\author{
Norazlin Abdullah ${ }^{1,2}$ (1) and Nyuk Ling Chin ${ }^{2, *(1)}$ \\ 1 Department of Technology and Natural Resources, Faculty of Applied Sciences and Technology, \\ Universiti Tun Hussein Onn Malaysia, UTHM Pagoh Campus, Pagoh Higher Education Hub, KM 1, \\ Jalan Panchor, Muar 84600, Johor, Malaysia; norazlinh@uthm.edu.my \\ 2 Department of Process and Food Engineering, Faculty of Engineering, Universiti Putra Malaysia, UPM, \\ Serdang 43400, Selangor, Malaysia \\ * Correspondence: chinnl@upm.edu.my; Tel.: +60-3-97696353
}

Citation: Abdullah N. and Chin N.L. Optimising Tropical Fruit Juice Quality Using Thermosonication-Assisted Extraction via Blocked Face-Centered Composite Design. Processes 2021, 9, 3. https://dx.doi.org/10.3390/pr9 010003

Received: 26 October 2020

Accepted: 16 November 2020

Published: 22 December 2020

Publisher's Note: MDPI stays neutral with regard to jurisdictional claims in published maps and institutional affiliations.

Copyright: (C) 2020 by the authors. Licensee MDPI, Basel, Switzerland. This article is an open access article distributed under the terms and conditions of the Creative Commons Attribution (CC BY) license (https: / / creativecommons.org/ licenses/by/4.0/).

\begin{abstract}
Extraction of tropical fruit juice using simple, efficient, and environmentally friendly technologies is gaining importance to produce high quality juices. Juice from pink-fleshed guava, pink-fleshed pomelo, and soursop was extracted using direct and indirect thermosonication methods by varying intensity, time, and temperature, and compared to those extracted using water bath incubation. Improvised models of juice yield, ascorbic acid, and total soluble solids responses were generated by eliminating insignificant model terms of the factors in full quadratic model using backward eliminating procedure. Main effects, 3D, or 4D plots for each response were developed based on factors that influenced the response. Results showed that the best extraction method for guava and pomelo juices were within indirect thermosonication method of $1 \mathrm{~kW}, 55^{\circ} \mathrm{C}$ and $30 \mathrm{~min}$, and $2.5 \mathrm{~kW}, 54{ }^{\circ} \mathrm{C}$ and $23 \mathrm{~min}$, respectively. Direct thermosonication method at $10 \%$ amplitude, $55^{\circ} \mathrm{C}$ for 2 to $10 \mathrm{~min}$ was more suitable for soursop juice. Thermosonicated extraction of tropical fruit juice can improve its juice yield, ascorbic acid content, and total soluble solids content.
\end{abstract}

Keywords: response surface methodology; ultrasound; guava; pomelo; soursop

\section{Introduction}

Preserving pink-fleshed guava, pink-fleshed pomelo, and soursop fruits in the form of juice concentrates is useful, as these three fruits are excellent in terms of fighting cancer and are claimed as cancer therapy fruits [1,2]. The pink-fleshed guava contains lycopene, which can prevent skin damage from ultraviolet rays and offers protection from prostate cancer. It is also rich in carotene, which can protect against lung and oral cavity cancers. The high vitamin $C$ content of the pink-fleshed pomelo helps to strengthen and maintain elasticity of arteries. In addition to being good for the digestive system, pomelo can aid in weight loss process because the fat burning enzyme in pomelo can help to absorb and reduce starch and sugar in the body. The pink-fleshed pomelo is slightly sweeter and more nutritious than other pomelos because of its darker pigment. Soursop pulp is white and juicy and has a delightful sour-sweet aroma with a yogurt-like taste [3], in addition to containing annonaceous acetogenins, which are prostate cancer chemopreventive compounds [1]. The fruit is widely used in anticancer folk therapies in North, Central, and South America, and Southeast Asia [4].

In the ascending order of the amount of free-run juice from fresh fruit, the pink-fleshed guava ranks the lowest, followed by the soursop, and pink-fleshed pomelo. The pinkfleshed guava and soursop both contain high starch levels of $13 \%$ [5] and $27.3 \%$ [6], respectively. The high starch content and the thick, creamy, and fleshy, pink-fleshed guava and soursop pulps result in difficulty in cell wall disruption of the fruit tissue. Thus, only a 
small amount of juice can be pressed or squeezed out. A more advanced extraction process is needed for production of these fruit juices. The pink-fleshed pomelo fruit, which is non-starchy [7] and has high watery properties, can serve as a control for extraction process comparisons.

Ultrasound is well known for its use in inactivating food spoilage, yeast, and pathogenic microorganisms [8-13]. In juice extraction, ultrasound can produce greater yields of juice [14], reduce time of juice extraction because of heat and mass transfer enhancement, and save extraction energy via facilitating extraction at medium temperature levels. The combination of low frequency ultrasound with mild heat can help in reducing processing temperature and time by 16 and 55\%, respectively, minimising the negative effects on fruit juices quality and makes the processing more economically feasible [15]. The combination of ultrasound and mild heat treatment is also known as thermosonication. The thermosonication treatment is useful in acting against thermo-resistant enzymes where it is difficult to denature by thermal treatment alone. The use of extreme heat could lead to adverse changes in juice quality like cooked flavour and caramelisation [15-19]. Since enzymes are more thermo-resistant than microorganisms in citrus juices, the inactivation of enzymes promises achievement of required number of microbial destruction for spoilage prevention [20]. The thermosonication treatment can also penetrate fruit cell walls and release cell contents trapped inside fruit tissues. Although ultrasonically assisted extraction processes are able to release contents such as sugar, medicinal compounds, carotenoids, and protein from biological materials by disrupting cell walls [21,22], such techniques have not been used to extract juice from difficult-to-juice produce such as those having high starch content and creamy fruit pulp. Sin et al. [23] and Lee et al. [24] applied hot water extraction method to extract sapodilla and banana juice, respectively, while Cendres et al. [25] extracted juice from grapes, plums, and apricots using microwaves.

In extraction experiments that cannot be completed within a day, a blocking approach is used to obtain more precise and consistent results. The blocked face-centred central composite design, an experimental design in response surface methodology (RSM) is used to generate predictive equations to optimise thermosonic-assisted juice extraction process as opposed to the unblocked face-centred central composite design used in optimising hot water extraction for sapodilla juice [23] and banana juice [24]. The objective of this study was to determine the optimum extraction method and conditions for producing higher juice yield with maximum ascorbic acid and total soluble solids levels of pink-fleshed guava, pink-fleshed pomelo, and soursop fruit juices.

\section{Materials and Methods}

\subsection{Fruit Pulp Preparation}

Matured, pink-fleshed guava fruits at 75\% ripeness with a pronounced typical aroma and yellow skin were purchased from Sime Darby Beverages Sdn. Bhd. The ripened fruits were washed under running tap water and any floral remnants at the apex were removed after the outer part dried. Then, the tip ends were cut with a sharp knife prior to dicing the fruit into small pieces.

Pink-fleshed pomelo fruits were purchased from Perniagaan Buah-buahan Ah Yew, Bidor, Perak. Pomelo with yellow rinds were chosen for peeling process. The very thick spongy rind was cut into four sections as close as possible to the flesh of the pomelo. Each section of peel was pulled away from the fruit prior to slicing the fruit and breaking it in half. The seeds and remaining pith, which are bitter, were completely removed.

Matured green soursop fruits were purchased from Federal Agricultural Marketing Authority (FAMA) of Malaysia. The fruits were allowed to ripen in an air-conditioned $\left(18 \pm 2{ }^{\circ} \mathrm{C}\right)$ room for 3 to 4 days prior to processing. They were considered ripened when they were soft to touch and the shiny green colour turned to lack-lustre green or yellowishgreen. Approximately $5 \mathrm{~kg}$ of ripened fruits were processed while waiting for remaining fruits to ripen within 1 to 2 days. The fruits were washed and cut into half, cored, their skin hand-peeled, and seeds removed from the pulp manually. 
For each fruit, $2.5 \mathrm{~kg}$ of pulp was crushed into a mash using a $1300 \mathrm{~W}$ commercial food blender (XB409, Ceado, Italy) with a pulse duration of $60 \mathrm{~s}$ at a high speed of 28,000 rpm, then $30 \mathrm{~s}$ off and $60 \mathrm{~s}$ at a low speed of 22,000 rpm for complete homogenisation of pulp mash.

\subsection{Thermosonic-Assisted Extraction}

The direct thermosonic-assisted extraction as shown in Figure 1 was performed using a $400 \mathrm{~W}$ digital ultrasonic processor (S-450D, Branson, MO, USA) with its probe tip immersed to a depth of $25 \mathrm{~mm}$ into a 150-mL beaker containing pulp mixture samples at ultrasonic amplitudes of 10,55 , or $100 \%$ for 2,6 , or $10 \mathrm{~min}$. For indirect thermosonic-assisted extraction as illustrated in Figure 2, a glass bottle of the pulp sample mixture was partially immersed in an ultrasonic water bath [26], which contains distilled water as a medium to spread waves at a power of $1,1.75$, or $2.5 \mathrm{~kW}$ for 10,20 , or $30 \mathrm{~min}$. The motion frequency, power, and amplitudes of ultrasonic energy dictate the intensity of treatment where high shear forces induced produce high-energy microbubbles that accelerated juice extraction process through release of energy by direct injection into fruit cell wall to obtain a high volume of extracted juice. Each extraction was conducted at three temperatures, i.e., 25, 40, and $55^{\circ} \mathrm{C}$, and the pulp mixture samples were mixtures of $50 \mathrm{~g}$ of blended pulp with distilled water at ratio of 1:1. The specified temperature was maintained manually by adding cold water into a water container that places the beaker for direct thermosonication or applying continuous flow of water in the bath for indirect thermosonication. The extraction by incubation in a water bath acted as a control with pulp mixture samples added in glass bottles, shaken for 30,75 , and $120 \mathrm{~min}$ at 20,100, and $180 \mathrm{rpm}$ in a shaking water bath (BS-21, Lab Companion, Korea) at incubation temperatures of 25,40 , and $55^{\circ} \mathrm{C}$.

The treated pulp was separated from the juice by centrifugation at $4000 \mathrm{rpm}$ and $4{ }^{\circ} \mathrm{C}$ for 20 min using a refrigerated centrifuge (Mikro 22R, HettichZentrifugen, Germany). The supernatant was collected for determination of juice yield, ascorbic acid (AA) content, and total soluble solids (TSS) content.

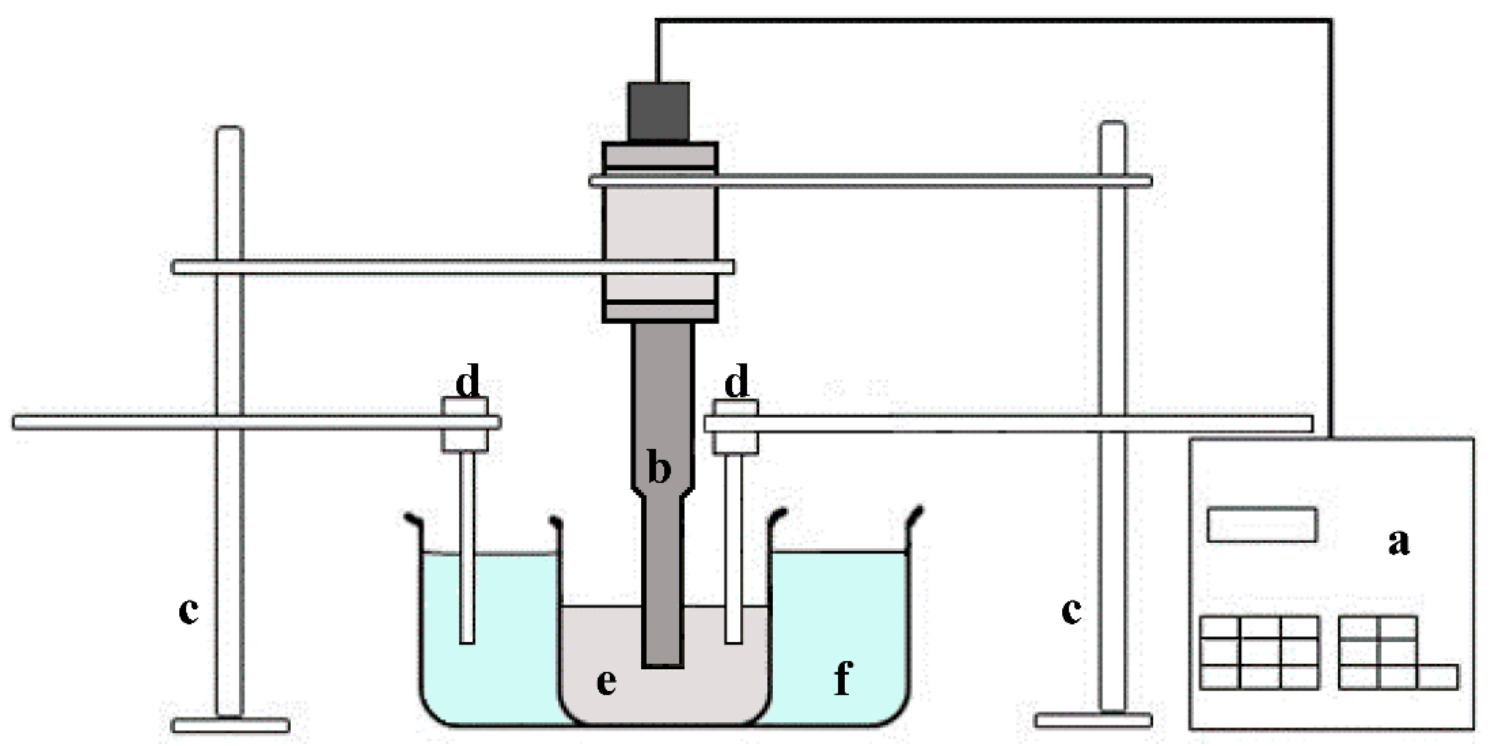

Figure 1. Experimental setup for direct thermosonic-assisted extraction. (a) Ultrasonic processor, (b) sonicator probe, (c) retort stand, (d) temperature probe, (e) fruit juice, and (f) water for controlling temperature. 


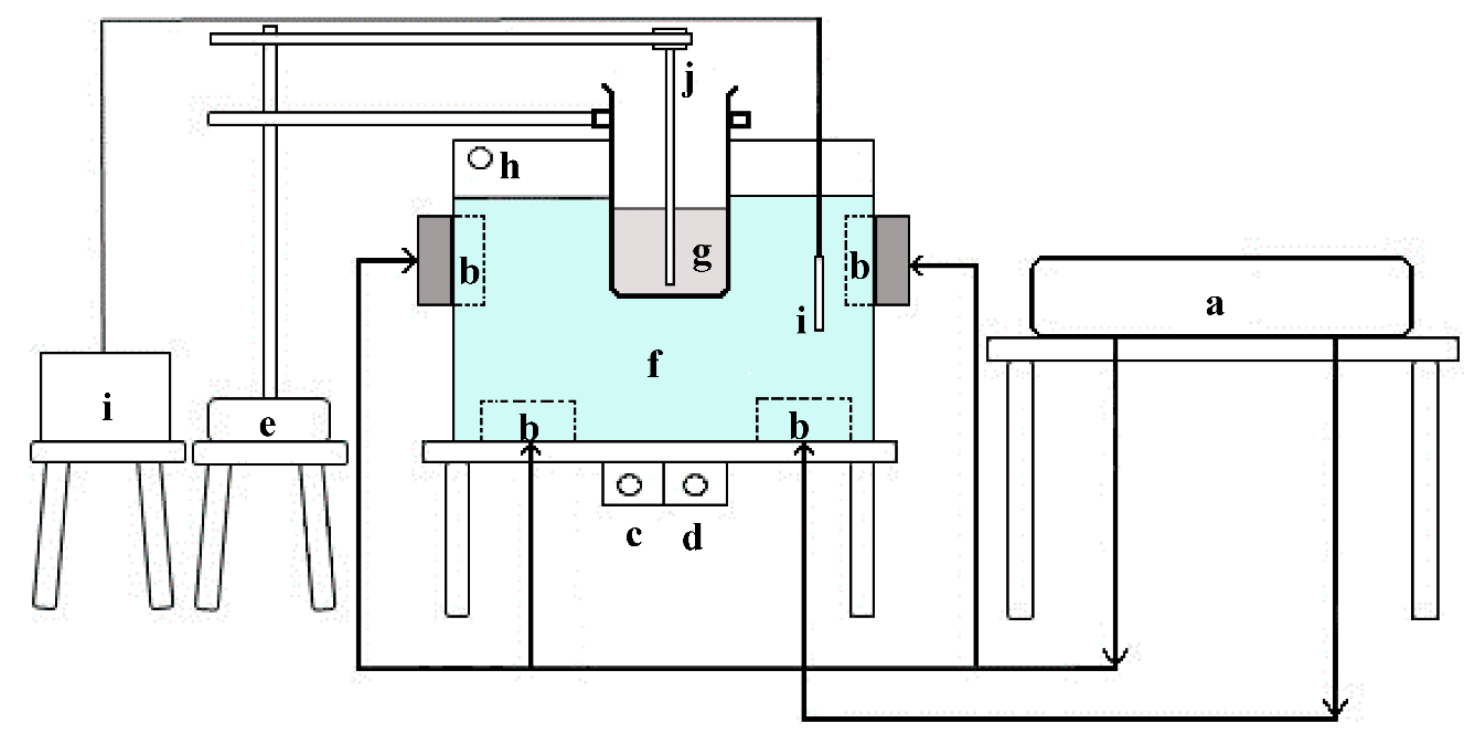

Figure 2. Experimental setup for indirect thermosonic-assisted extraction. (a) Ultrasonic generator, (b) transducer, (c) water inlet valve, (d) water drain valve, (e) retort stand, (f) ultrasonic tank, (g) fruit juice, (h) overflow outlet, (i) heater, and (j) temperature probe.

\subsection{Blocked Face-Centred Central Composite Design}

The blocked face-centred central composite design provides high-quality predictions over the entire design space and does not require using points outside the original factor range. Blocking was required to increase precision of experiments as variations of each batch of fruits could not be controlled, and all runs could not be completed within a day. Face-centred refers to alpha value of one and was chosen because the points were at operational limits, and equipment used could set the parameters to certain values only. The combination of factors for each run was generated and arranged using commercial software (MINITAB ${ }^{\circledR}$ Release 14, Minitab Inc., State College, PA, USA).

Table 1 shows experimental runs designed for one batch of fruits. There were 20 runs for each batch of fruits with three replications for each block and batch varying three factors, intensity, time, and temperature, at three levels, $-1,0$, and 1 , which gave total runs of 60 . Responses were measured as percentage change of juice yield, ascorbic acid (AA), and total soluble solids (TSS) content. Fitted regression models were obtained using MINITAB, whereas 4D surface plot was generated using ThreeDify Excel Grapher (v.3.3.8, ThreeDify Inc., Ottawa, ON, Canada) software. The plotted graph chosen depended on the significant factors involved in the improvised models.

The second-order model is widely used in RSM because of its flexibility in taking on a wide variety of functional forms and a good capability to estimate the true response surface [27]. As blocking was used in this study, the second-order model, Equations (1) and (2), were necessary to fit the data $[28,29]$. The best-fitted models were chosen, and values for the combined factors that satisfied all optimum responses simultaneously were generated.

$$
\begin{gathered}
Y=\beta_{0}+\beta_{01}+\beta_{02}+\beta_{03}+\beta_{04}+\beta_{05}+\beta_{06}+\beta_{07}+\beta_{08}+\beta_{09}+\sum_{j=1}^{k} \beta_{j} x_{j}+\sum_{j=1}^{k} \beta_{j j} x_{j}^{2}+\sum_{i<j=2}^{k} \beta_{i j} x_{i} x_{j} \\
\beta_{09}=-\left(\beta_{01}+\beta_{02}+\beta_{03}+\beta_{04}+\beta_{05}+\beta_{06}+\beta_{07}+\beta_{08}\right)
\end{gathered}
$$

where $Y$ is the response; $\beta_{0}$ is the constant for intercept; $\beta_{01}$ to $\beta_{09}$ are the constant for blocks; $\beta_{j}$ is the linear coefficient; $\beta_{j j}$ is the quadratic coefficient, and $\beta_{i j}$ is the interaction coefficient. $x_{i}$ and $x_{j}$ are independent variables ( $i$ and $j$ are in the range of 1 to $k$ ). $k$ is the number of independent variables $(k=3)$. 
Table 1. Design of experiments with coded variable levels.

\begin{tabular}{|c|c|c|c|c|c|}
\hline Batch & Run & Block & Intensity $^{a}$ & Time (minutes) & Temperature $\left({ }^{\circ} \mathrm{C}\right)$ \\
\hline \multirow{20}{*}{$1^{b}$} & 1 & 1 & -1 & -1 & -1 \\
\hline & 2 & 1 & 1 & 1 & -1 \\
\hline & 3 & 1 & 1 & -1 & 1 \\
\hline & 4 & 1 & -1 & 1 & 1 \\
\hline & 5 & 1 & 0 & 0 & 0 \\
\hline & 6 & 1 & 0 & 0 & 0 \\
\hline & 7 & 2 & 1 & -1 & -1 \\
\hline & 8 & 2 & -1 & 1 & -1 \\
\hline & 9 & 2 & -1 & -1 & 1 \\
\hline & 10 & 2 & 1 & 1 & 1 \\
\hline & 11 & 2 & 0 & 0 & 0 \\
\hline & 12 & 2 & 0 & 0 & 0 \\
\hline & 13 & 3 & -1 & 0 & 0 \\
\hline & 14 & 3 & 1 & 0 & 0 \\
\hline & 15 & 3 & 0 & -1 & 0 \\
\hline & 16 & 3 & 0 & 1 & 0 \\
\hline & 17 & 3 & 0 & 0 & -1 \\
\hline & 18 & 3 & 0 & 0 & 1 \\
\hline & 19 & 3 & 0 & 0 & 0 \\
\hline & 20 & 3 & 0 & 0 & 0 \\
\hline
\end{tabular}

Factors points represent by coded values: $-1=$ Low level; $0=$ Centre point $+1=$ High level. ${ }^{\text {a }}$ Intensity represents motion frequency (rpm) for control, amplitude (\%) for direct thermosonication and power $(\mathrm{kW})$ for indirect thermosonication. ${ }^{\mathrm{b}}$ Each batch of fruits was replicated three times.

\subsection{Response Analyses}

The responses evaluated were the percentage change of juice yield, AA, and TSS content from the original fruit pulp-distilled water mixture before extraction process. The calculation of percentage change was performed using Equation (3) for each evaluated response.

Percentage change $(\%)=\frac{\text { Treated sample }- \text { Original fruit pulp and distilled water mixture }}{\text { Original fruit pulp and distilled water mixture }} \times 100$

The percentage of juice yield $(\% w / w)$ was calculated following Equation (4) $[23,24]$ based on weight of fruit pulp, distilled water and total centrifuged juice of each sample in duplicate.

$$
\text { Juice yield }(\%)=\frac{\text { Weight of supernatant }- \text { Weight of distilled water }}{\text { Weight of fruit pulp }} \times 100
$$

AA content was measured using the 2,6-dichlorophenol-indophenol visual titration method [11]. A $10 \mathrm{~mL}$ juice sample was brought to a $100 \mathrm{~mL}$ volume with $3 \%$ metaphosphoric acid prior to titration with a $10 \mathrm{~mL}$ metaphosphoric acid extract of the sample with 2,6-dichlorophenol-indophenol to the pink end-point. AA content was calculated following Equation (5) and averaged from quadruplicate samples.

Ascorbic acid content $(\mathrm{mg} / 100 \mathrm{~mL})=\frac{\text { Titre } \times \text { Dye factor } \times \text { Volume made up } \times 100}{\text { Aliquot of extract taken for estimation } \times \text { Weight of sample taken for estimation }}$

TSS content was determined using a digital refractometer (PAL-Alpha, Atago, Bellevue, WA, USA) and reported as degree Brix ( ${ }^{\circ}$ Brix). The analysis for TSS was performed in triplicate. 


\section{Results and Discussion}

\subsection{Materials Characterisation}

Table 2 shows the percentage of juice yield, AA, and TSS content of fresh pulp and fruit pulp mixture samples for guava, pomelo, and soursop. The AA and TSS content decreased by almost half from that of fresh fruit pulp after being mixed with distilled water in a ratio of one to one. The presented results are averages of all blocks.

Table 2. Properties ${ }^{a}$ of fresh fruit pulps and control mixtures.

\begin{tabular}{lcccccc}
\hline \multirow{2}{*}{ Response } & \multicolumn{3}{c}{ Fresh Fruit Pulp } & \multicolumn{3}{c}{ Pulp Mixture Sample } \\
\cline { 2 - 7 } & Guava & Pomelo & Soursop & Guava & Pomelo & Soursop \\
\hline Juice yield (\%) & \multirow{2}{*}{ ND } & ND & \multirow{2}{*}{ ND } & $\begin{array}{c}8.705 \\
\pm 4.619\end{array}$ & $\begin{array}{l}71.532 \\
\pm 7.980\end{array}$ & $\begin{array}{l}19.402 \\
\pm 5.381\end{array}$ \\
\hline AA content & 51.422 & 38.080 & 13.669 & 18.834 & 20.829 & 6.460 \\
$(\mathrm{mg} \mathrm{AA} / 100 \mathrm{~mL})$ & \pm 11.751 & \pm 3.017 & \pm 4.404 & \pm 4.684 & \pm 1.857 & \pm 1.638 \\
\hline TSS content & 8.024 & 10.648 & 15.026 & 3.231 & 5.156 & 6.109 \\
$\left({ }^{\circ}\right.$ Brix) & \pm 1.594 & \pm 0.466 & \pm 0.868 & \pm 0.601 & \pm 0.211 & \pm 0.501 \\
\hline
\end{tabular}

${ }^{a}$ Data are presented as the mean \pm standard deviation. ND means not determined.

\subsection{Response Surface Regression Analysis}

Both the independent and dependent variables were fitted to full quadratic models, and the response surface regressions were generated to check the goodness of model fit. The standard deviation (S) is important for checking data distribution. The $R^{2}$ is important for measuring how much variation in the response is explained by the model. The adjusted regression $\left(R^{2}\right.$ adj $)$ is useful for comparing models with different numbers of predictors. The $p$-value of $R^{2}$ is useful for determining the relationship between dependent and independent variables, and the $p$-value of lack-of-fit indicates whether an adequate model has been chosen. A lower $\mathrm{S}$ value, $p$-value of $R^{2}$ less than 0.05 and higher $R^{2}, R^{2}$ adj and $p$-value of lack of fit indicated a better data fit by the model. The $R^{2}$ can be small as long as the $p$-value of the regression coefficient is statistically significant $(p<0.05)$. The determination of $S, R^{2}, R^{2}$ adj and $p$-value of lack of fit were, however, performed in the background when the model term reduction was performed.

Table 3 lists the final fitted models for all responses from direct and indirect thermosonication-assisted extraction procedure and the control after considering values of $S, R^{2}, R^{2}$ adj, $p$-value of $R^{2}$, and lack-of-fit. The best-fitted model was necessary to obtain true information on the effect of all three factors to each response. The models were improved by removing insignificant model terms using a backwards elimination procedure to make them easier to work with while maintaining the predictive efficiency [30]. The models' terms in Table 3 interprets the relationships among responses of juice yield, AA, and TSS content and input factors of intensity, time, and temperature for guava, pomelo, and soursop.

Table 3. Improved models for percentage change of juice yield, AA, and TSS contents.

\begin{tabular}{ll}
\hline Response & Model \\
\hline Guava & \\
\hline & $J Y_{g, c}=-119.184+66.335 \beta_{01}+33.592 \beta_{02}+19.638 \beta_{03}+3.807 \beta_{04}-17.95 \beta_{05}-132.472 \beta_{06}-48.142 \beta_{07}-$ \\
& $33.835 \beta_{08}+\beta_{09}+0.245 t+1.755 T$ \\
& $A A_{g, c}=28.994-11.878 \beta_{01}-12.248 \beta_{02}-11.257 \beta_{03}-2.836 \beta_{04}+1.024 \beta_{05}+24.340 \beta_{06}+22.026 \beta_{07}-6.916 \beta_{08}+$ \\
Control & $\beta_{09}+0.265 M-0.194 t-0.182 T-0.003 M^{2}-0.002 M T+0.005 t T$ \\
& $T S S_{g, c}=26.709+0.551 \beta_{01}-19.729 \beta_{02}-10.189 \beta_{03}-7.374 \beta_{04}-7.687 \beta_{05}+8.208 \beta_{06}+19.308 \beta_{07}+7.413 \beta_{08}+$ \\
& $\beta_{09}+0.023 M-0.176 t+0.001 T$ \\
\hline
\end{tabular}


Table 3. Cont.

\begin{tabular}{|c|c|}
\hline Response & Model \\
\hline $\begin{array}{l}\text { Direct thermo- } \\
\text { sonication }\end{array}$ & $\begin{array}{l}J Y_{g, d s}=-358.544+29.421 \beta_{01}+42.911 \beta_{02}+33.138 \beta_{03}+75.117 \beta_{04}+19.311 \beta_{05}-80.813 \beta_{06}-53.193 \beta_{07}- \\
30.769 \beta_{08}+\beta_{09}-4.454 A+20.147 T+0.032 A^{2}-0.257 T^{2} \\
A A_{g, d s}=1.967-4.092 \beta_{01}-4.647 \beta_{02}+2.543 \beta_{03}-9.729 \beta_{04}-5.947 \beta_{05}+12.754 \beta_{06}+19.029 \beta_{07}-9.351 \beta_{08}+\beta_{09}+ \\
0.192 A+1.125 t \\
T S S_{g, d s}=1.849+9.301 \beta_{01}-12.067 \beta_{02}-3.032 \beta_{03}-5.049 \beta_{04}-2.751 \beta_{05}+1.509 \beta_{06}+4.093 \beta_{07}+2.321 \beta_{08}+\beta_{09}+ \\
0.382 A+0.529 t-0.002 A^{2}\end{array}$ \\
\hline $\begin{array}{l}\text { Indirect } \\
\text { thermo- } \\
\text { sonication }\end{array}$ & $\begin{array}{l}J Y_{g, i s}=-207.698+8.571 \beta_{01}+22.168 \beta_{02}+9.177 \beta_{03}+18.419 \beta_{04}-35.592 \beta_{05}-44.681 \beta_{06}-60.351 \beta_{07}- \\
88.409 \beta_{08}+\beta_{09}+4.323 T \\
A A_{g, i s}=35.697-0.757 \beta_{01}-6.128 \beta_{02}+1.696 \beta_{03}-8.022 \beta_{04}-5.418 \beta_{05}+12.125 \beta_{06}+24.723 \beta_{07}-11.015 \beta_{08}+ \\
\beta_{09}-1.844 t+0.047 t^{2} \\
T S S_{g, i s}=59.548+2.596 \beta_{01}-15.611 \beta_{02}-8.043 \beta_{03}-6.927 \beta_{04}-3.599 \beta_{05}+9.601 \beta_{06}+11.603 \beta_{07}+2.356 \beta_{08}+ \\
\beta_{09}-23.038 P-1.082 T+6.491 P^{2}+0.014 T^{2}\end{array}$ \\
\hline \multicolumn{2}{|l|}{ Pomelo } \\
\hline Control & $\begin{array}{l}J Y_{p, c}= \\
-14.473+1.021 \beta_{01}-11.193 \beta_{02}-8.285 \beta_{03}-7.267 \beta_{04}-10.846 \beta_{05}+13.429 \beta_{06}-4.978 \beta_{07}+4.132 \beta_{08}+\beta_{09}+0.368 T \\
A A_{p, c}= \\
-6.706+1.924 \beta_{01}-2.790 \beta_{02}+5.741 \beta_{03}-3.565 \beta_{04}-8.983 \beta_{05}+4.753 \beta_{06}+0.193 \beta_{07}-0.752 \beta_{08}+\beta_{09}+0.0356 t \\
T S S_{p, c}=-4.672-0.739 \beta_{01}+0.410 \beta_{02}-1.101 \beta_{03}-0.531 \beta_{04}+3.331 \beta_{05}+1.204 \beta_{06}-0.425 \beta_{07}-0.328 \beta_{08}+\beta_{09}+ \\
0.005 t+0.221 T-0.002 T^{2}\end{array}$ \\
\hline $\begin{array}{l}\text { Direct thermo- } \\
\text { sonication }\end{array}$ & $\begin{array}{l}J Y_{p, d s}=4.929+3.142 \beta_{01}+9.273 \beta_{02}-4.372 \beta_{03}-6.998 \beta_{04}-5.789 \beta_{05}+5.629 \beta_{06}-5.781 \beta_{07}+6.174 \beta_{08}+\beta_{09}- \\
0.021 A+0.135 t-0.013 A t \\
A A_{p, d s}=-23.401+3.475 \beta_{01}+1.600 \beta_{02}+5.993 \beta_{03}-4.219 \beta_{04}-9.351 \beta_{05}+0.359 \beta_{06}-0.648 \beta_{07}-0.691 \beta_{08}+ \\
\beta_{09}+0.067 A+0.016 t+0.929 T-0.009 T^{2}-0.002 A T \\
T S S_{p, d s}=-0.730-0.184 \beta_{01}-0.070 \beta_{02}-1.784 \beta_{03}-0.796 \beta_{04}+3.026 \beta_{05}+1.182 \beta_{06}+0.682 \beta_{07}+0.524 \beta_{08}+ \\
\beta_{09}+0.008 A+0.034 t+0.029 T+0.003 A t\end{array}$ \\
\hline $\begin{array}{l}\text { Indirect } \\
\text { thermo- } \\
\text { sonication }\end{array}$ & $\begin{array}{l}J Y_{p, i s}=-35.908+2.264 \beta_{01}+7.274 \beta_{02}-9.292 \beta_{03}-2.880 \beta_{04}-14.726 \beta_{05}+11.261 \beta_{06}-2.517 \beta_{07}+5.100 \beta_{08}+ \\
\beta_{09}+1.861 T-0.021 T^{2} \\
A A_{p, i s}=1.272+2.407 \beta_{01}-1.476 \beta_{02}+4.210 \beta_{03}-2.825 \beta_{04}-7.596 \beta_{05}-1.258 \beta_{06}+2.863 \beta_{07}-0.667 \beta_{08}+\beta_{09}- \\
2.134 P-0.164 T+0.101 P T \\
T S S_{p, i s}=-1.735+0.367 \beta_{01}-0.463 \beta_{02}-1.477 \beta_{03}-0.330 \beta_{04}+2.693 \beta_{05}+1.545 \beta_{06}-0.429 \beta_{07}-0.033 \beta_{08}+\beta_{09}+ \\
1.682 P+0.199 t-0.034 T-0.782 P^{2}-0.004 t^{2}+0.031 P T\end{array}$ \\
\hline \multicolumn{2}{|l|}{ Soursop } \\
\hline Control & $\begin{array}{l}J Y_{s, c}=-98.879-9.461 \beta_{01}-40.967 \beta_{02}-28.190 \beta_{03}+39.719 \beta_{04}-20.356 \beta_{05}+0.347 \beta_{06}+2.809 \beta_{07}+10.248 \beta_{08}+ \\
\beta_{09}+0.272 M+0.197 t+1.456 T \\
A A_{s, c}= \\
6.471+14.336 \beta_{01}-22.515 \beta_{02}+8.432 \beta_{03}+24.046 \beta_{04}-12.567 \beta_{05}+1.852 \beta_{06}-5.9679 \beta_{07}-7.471 \beta_{08}+\beta_{09}-0.290 T \\
T S S_{s, c}=-6.729-2.236 \beta_{01}+7.774 \beta_{02}-9.679 \beta_{03}+21.366 \beta_{04}-6.394 \beta_{05}-6.120 \beta_{06}-8.946 \beta_{07}+7.293 \beta_{08}+ \\
\beta_{09}+0.001 M+0.414 T+0.001 M^{2}-0.002 M T\end{array}$ \\
\hline $\begin{array}{l}\text { Direct thermo- } \\
\text { sonication }\end{array}$ & $\begin{array}{l}J Y_{s, d s}=-8.500+0.887 \beta_{01}-17.136 \beta_{02}-6.785 \beta_{03}-37.821 \beta_{04}+17.277 \beta_{05}+14.581 \beta_{06}-2.340 \beta_{07}-8.890 \beta_{08}+ \\
\beta_{09}-0.779 A+0.427 T \\
A A_{s, d s}=17.871+5.324 \beta_{01}-23.631 \beta_{02}+18.792 \beta_{03}+14.569 \beta_{04}-13.571 \beta_{05}+21.751 \beta_{06}-13.381 \beta_{07}-3.718 \beta_{08}+ \\
\beta_{09}-0.576 A+0.005 A^{2} \\
T S S_{s, d s}=9.100-3.037 \beta_{01}+6.608 \beta_{02}-9.097 \beta_{03}+13.090 \beta_{04}-6.514 \beta_{05}-6.467 \beta_{06}-6.879 \beta_{07}+10.683 \beta_{08}+ \\
\beta_{09}-0.152 A+0.002 A^{2}\end{array}$ \\
\hline $\begin{array}{l}\text { Indirect } \\
\text { thermo- } \\
\text { sonication }\end{array}$ & $\begin{array}{l}J Y_{s, i s}=-183.544+1.882 \beta_{01}-40.425 \beta_{02}-32.511 \beta_{03}+20.379 \beta_{04}-7.181 \beta_{05}-15.234 \beta_{06}+7.54 \beta_{07}+30.705 \beta_{08}+ \\
\beta_{09}+10.345 t+1.758 T-0.248 t^{2} \\
A A_{s, i s}= \\
10.877+4.169 \beta_{01}-25.789 \beta_{02}+23.169 \beta_{03}+7.841 \beta_{04}-16.359 \beta_{05}-4.051 \beta_{06}+1.871 \beta_{07}+7.278 \beta_{08}+\beta_{09}-0.319 T \\
T S S_{s, i s}=1.909-1.125 \beta_{01}+7.76 \beta_{02}-10.196 \beta_{03}+13.617 \beta_{04}-7.685 \beta_{05}-4.491 \beta_{06}-7.662 \beta_{07}+10.642 \beta_{08}+ \\
\beta_{09}-7.420 P+0.362 T+4.191 P^{2}-0.1400 P T\end{array}$ \\
\hline
\end{tabular}

$J Y=$ juice yield; $g=$ guava; $p=$ pomelo; $s=$ soursop; $c=$ control; $d s=$ direct thermosonication; is = indirect thermosonication; $M=$ motion frequency; $t=$ time; $T=$ temperature; $A=$ amplitude; $P=$ power, $\beta_{01}$ to $\beta_{09}$ are the constant for blocks: at each block, one of them is equal to 1 for involved block, whereas the rest are equal to zero, except for $\beta_{09}$ (Equation (2)). 


\subsection{Extraction Process Optimisation}

For response optimisation, the combined goals of maximum increase in juice yield, AA, and TSS content for the studied range of all three input factors were satisfied by the conditions given in Table 4.

Table 4. Optimum values for extracting tropical fruit juices.

\begin{tabular}{lccc}
\hline \multicolumn{1}{c}{ Factors } & Guava & Pomelo & Soursop \\
\hline Control & & & \\
\hline Motion frequency (rpm) & 20 & $\mathrm{NS}$ & 180 \\
Time (minutes) & 120 & 120 & 120 \\
Temperature $\left({ }^{\circ} \mathrm{C}\right)$ & 55 & 55 & 55 \\
\hline Direct thermosonication & & & \\
\hline Amplitude $(\%)$ & 100 & 33 & 10 \\
Time (minutes) & 10 & 10 & $\mathrm{NS}$ \\
Temperature $\left({ }^{\circ} \mathrm{C}\right)$ & 39 & 54 & \\
\hline Indirect thermosonication & & & 1 \\
\hline Power $(\mathrm{kW})$ & 1 & 2.5 & 55 \\
Time (minutes) & 30 & 23 & \\
Temperature $\left({ }^{\circ} \mathrm{C}\right)$ & 55 & 54 & \\
\hline
\end{tabular}

NS means not significant.

Figure 3 shows the responses of the optimised method of guava juice extraction. The juice yield was affected by temperature linearly, where $47^{\circ} \mathrm{C}$ was a point of change of the positive and negative juice yield percentage. It is believed that $47^{\circ} \mathrm{C}$ is the cut-off temperature for water reactivity due to ultrasonic waves where trapped water molecules inside guava fruit tissue moved faster until they could break the cell walls for water release. Below $47^{\circ} \mathrm{C}$, the trapped water inside guava fruit tissue was not released and remained in the solid matter during centrifugation process. The AA content displayed a minimum increase after $20 \mathrm{~min}$ of extraction, whereas a minimum positive change of TSS content occurred in the middle range of the studied temperatures and power levels.

Figure 4 illustrates responses of optimised method of pomelo juice extraction, where temperatures above $28^{\circ} \mathrm{C}$ were effective in increasing juice yield. Juice yield started to decrease drastically above $42{ }^{\circ} \mathrm{C}$ until the investigated temperature of $55^{\circ} \mathrm{C}$, where the temperature was high and water loss occurred due to evaporation. The AA content increased under a combination of high power and temperature, at $2.3 \mathrm{~kW}$ and a temperature of $45^{\circ} \mathrm{C}$. The change of TSS content was influenced by all three factors of power, time, and temperature. The combination of high power, time, and temperature provided minimal increase in TSS content. The highest range of TSS content increment of 2 to $2.5 \%$ occurred at high power as well as a short time and low temperature.

Figure 5 illustrates responses of optimised method of soursop juice extraction. Juice yield increased when the amplitude was low and temperature was high. Amplitude affected both the AA and TSS content, and they displayed positive changes for the studied amplitude range. The minimum increase in AA content occurred at an amplitude of $60 \%$, whereas the minimum increase in TSS content occurred at 38\% amplitude. The AA content was high when low amplitude was applied, whereas high TSS content occurred at high amplitude.

The sonication methods were able to increase AA content in all three fruit juices via removal of dissolved oxygen which favoured decomposition of AA during cavitation [31], whereas the negative change of AA content in pomelo juice was due to degrading of AA in acid solutions [32]. The content of TSS of all three fruit juices extracted using optimised method was greatly affected by heat and/or intensity of direct and indirect ultrasound systems. These factors were also found to be effective in the extraction of mayhaw fruit juice [33]. 

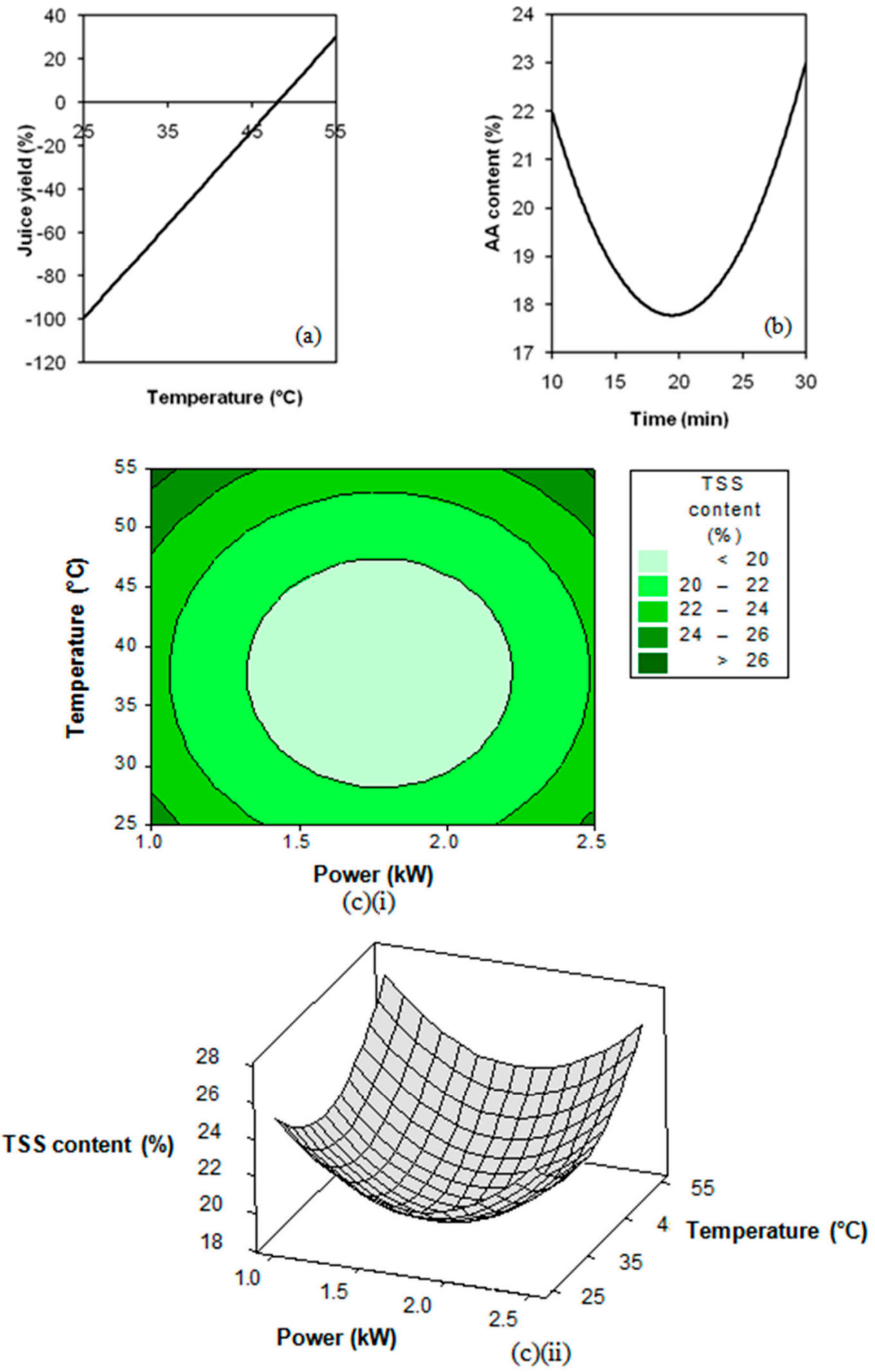

Figure 3. Plots of indirect thermosonication-assisted guava juice extraction responses. (a) Main effect plot of juice yield, (b) Main effect plot of AA content, (c) (i) 3D contour plot and (ii) 3D surface plot of TSS content. 

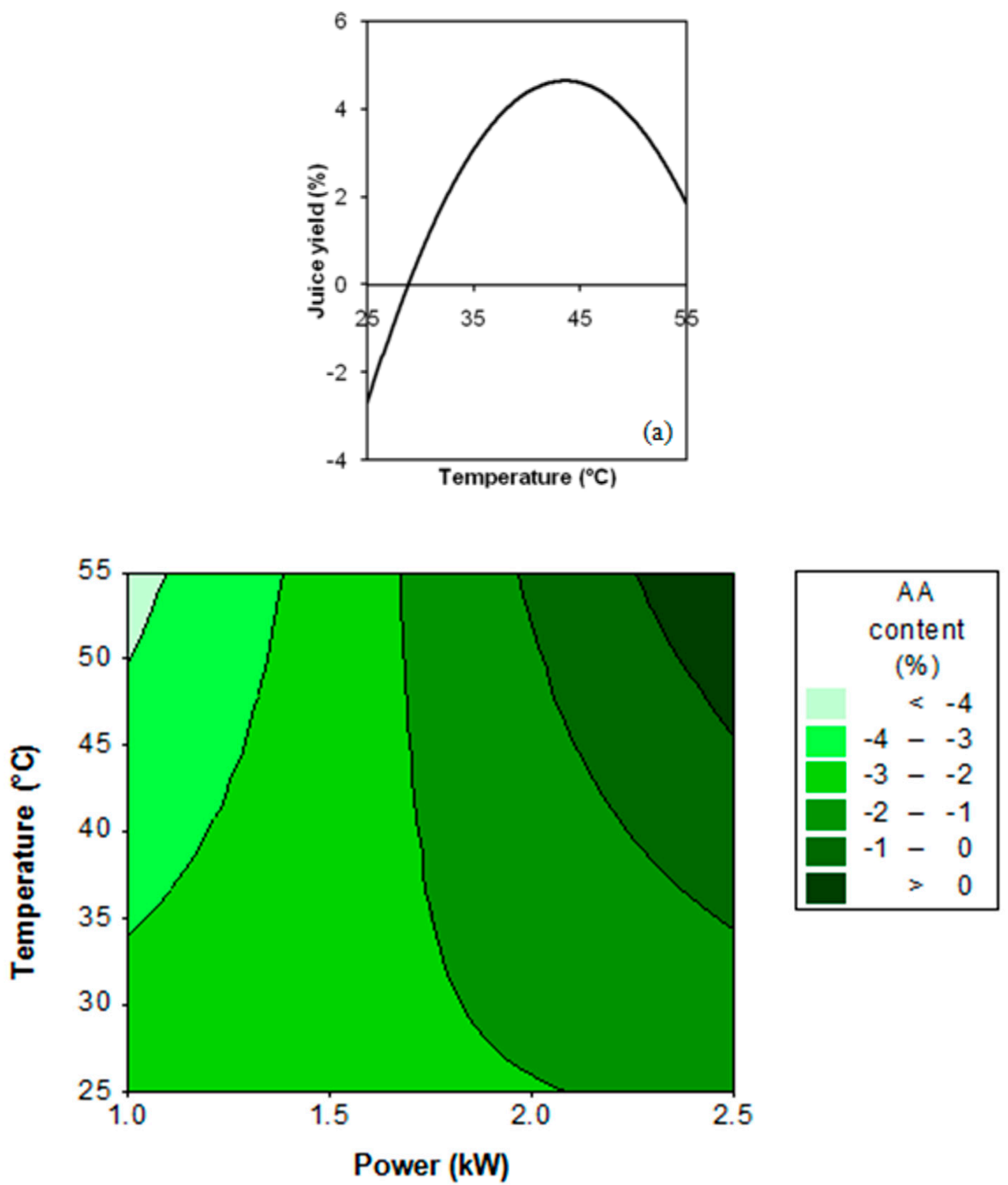

(b)(i)

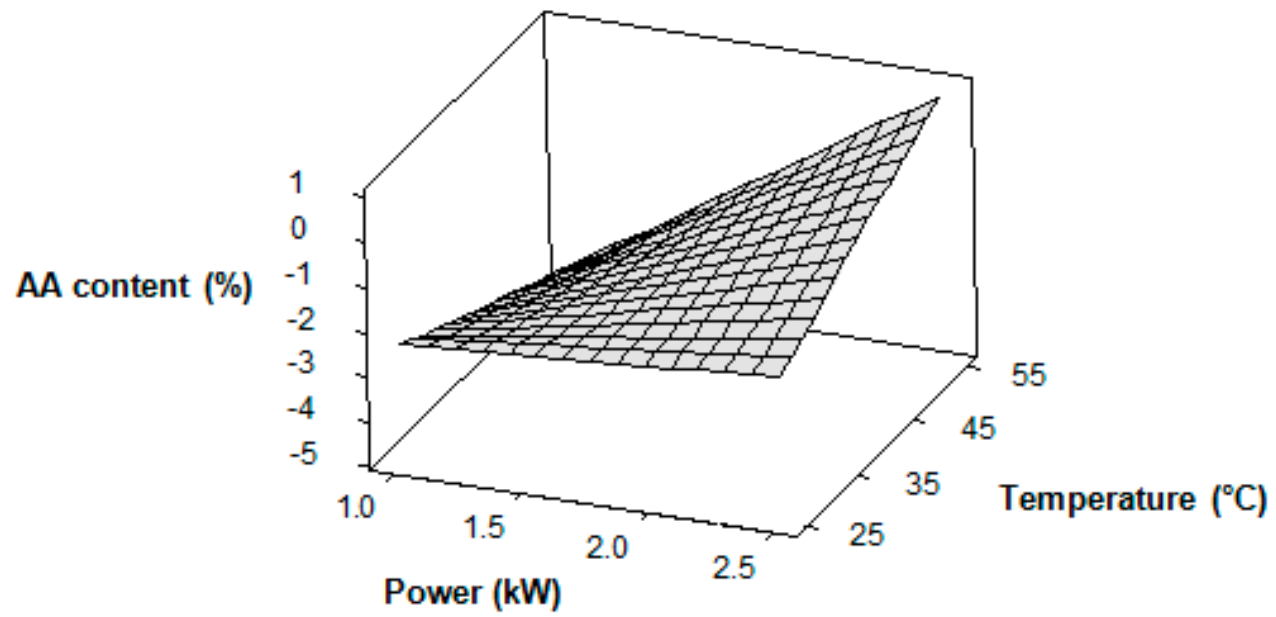

(b)(ii)

Figure 4. Cont. 


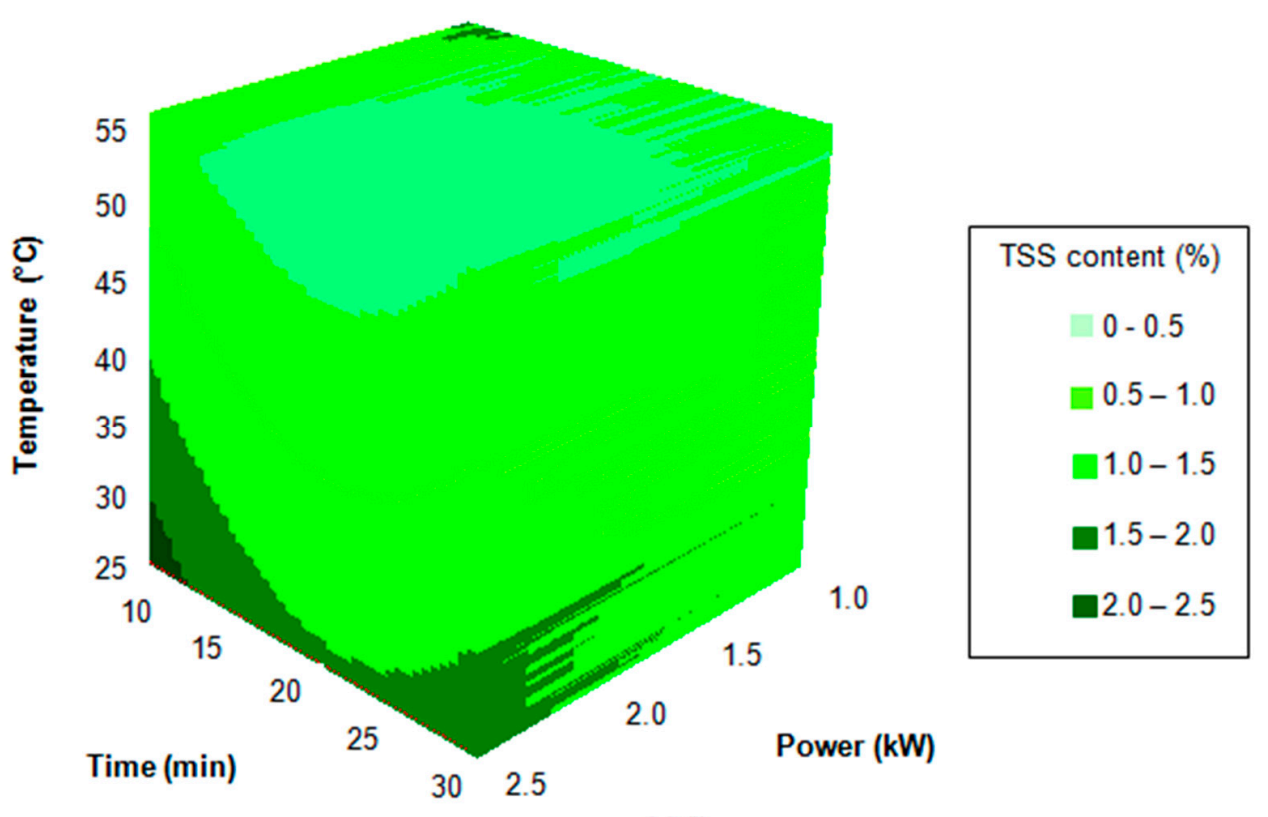

(c)(i)

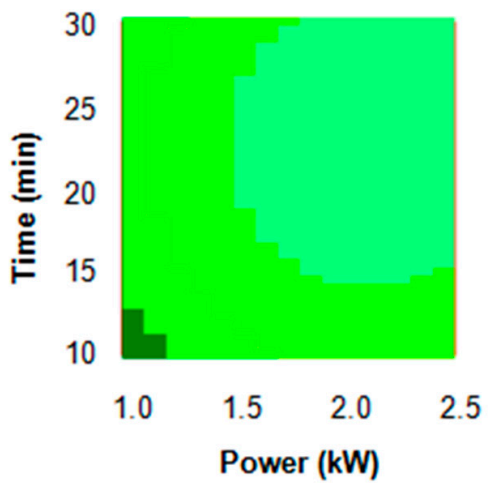

(c)(ii)

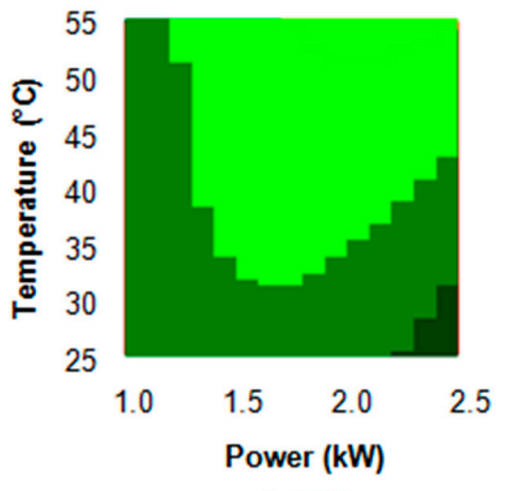

(c)(iii)

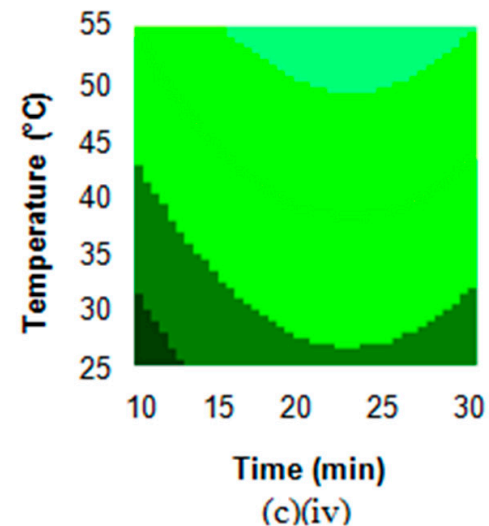

Figure 4. Plots of indirect thermosonication-assisted pomelo juice extraction responses. Plots of indirect thermosonicationassisted pomelo juice extraction responses. (a) Main effect plot of juice yield. (b) (i) 3D contour plot and (ii) 3D surface plot of AA content. (c) (i) 4D surface plot, (ii) 4D power-time contour plot, (iii) 4D power-temperature contour plot and (iv) 4D time-temperature contour plot of TSS content. 

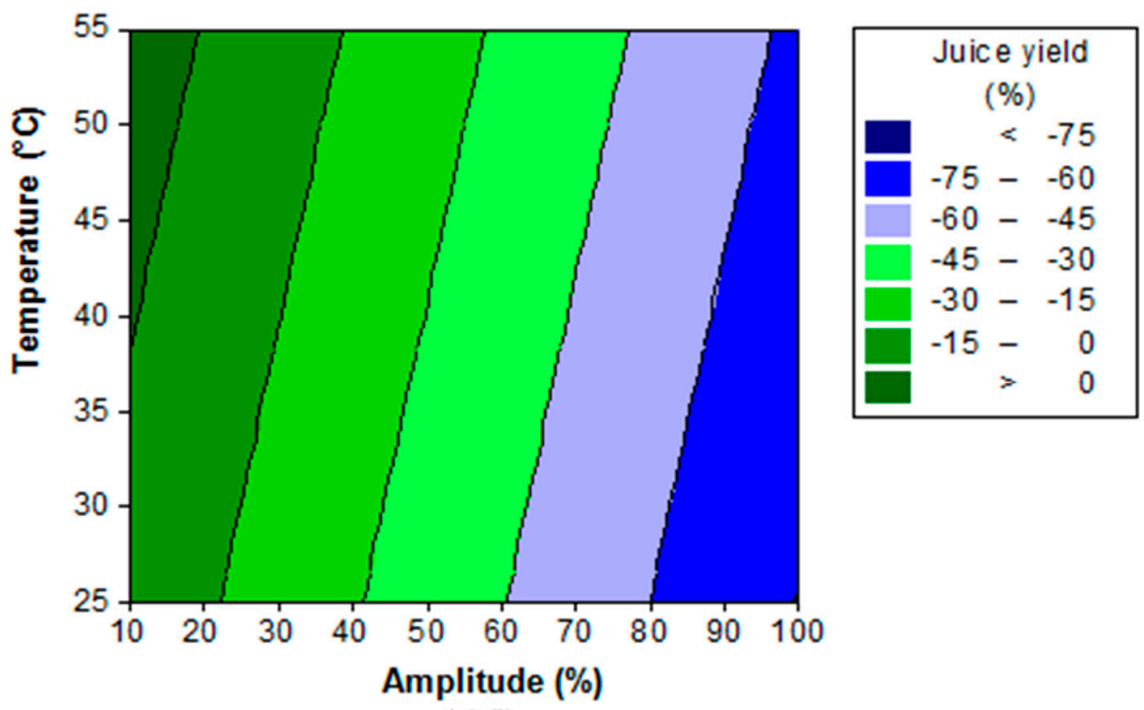

(a)(i)
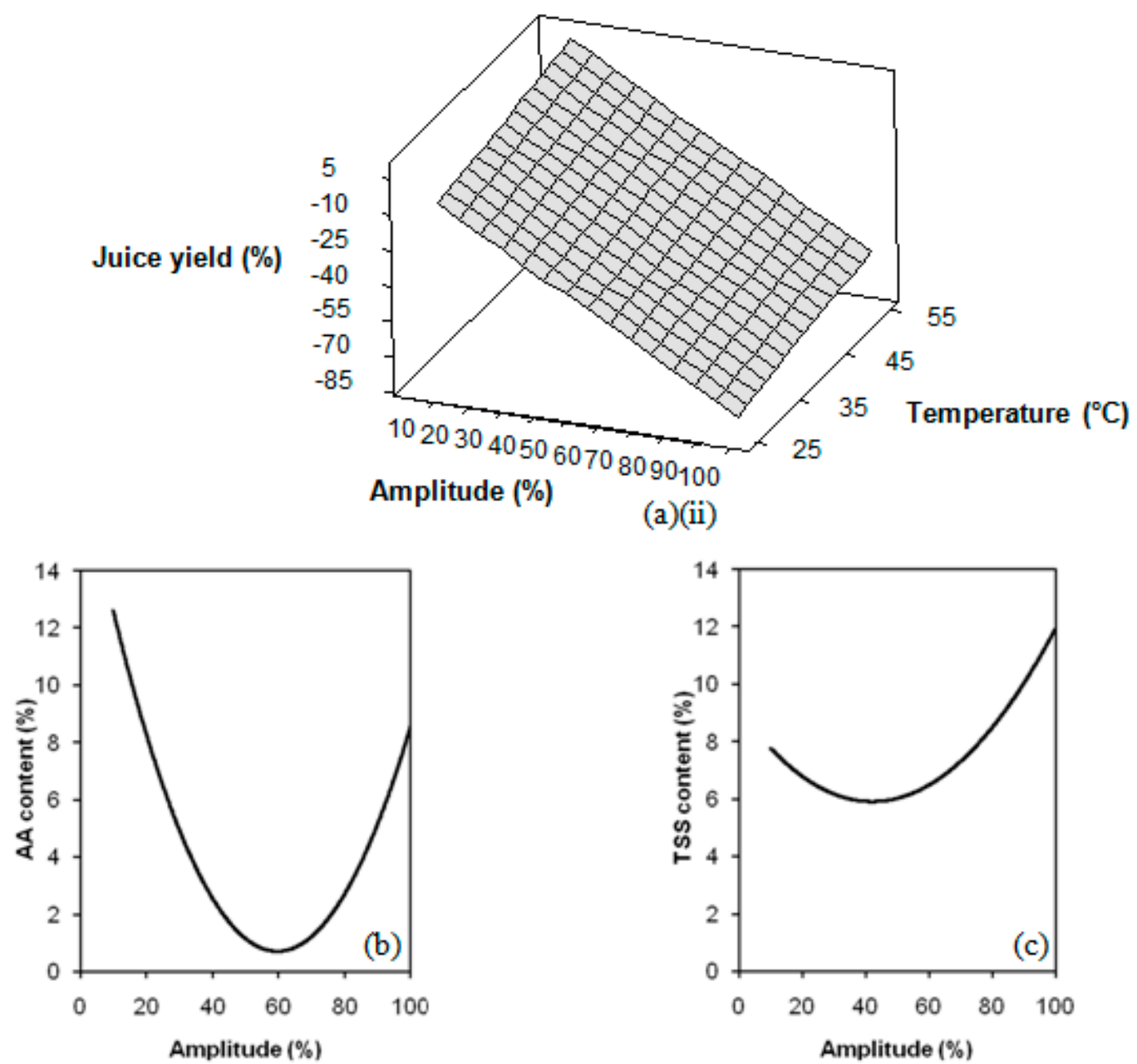

Figure 5. Plots of direct thermosonication-assisted soursop juice extraction responses. (a) (i) 3D contour plot and (ii) 3D surface plot of juice yield, (b) Main effect plot of AA content and (c) Main effect plot of TSS content. 


\subsection{Adequacy of Models and Verification}

The adequacy of the models to predict optimum combined responses was validated experimentally using optimum conditions listed in Table 4 . Table 5 shows that the trends and sequences were reasonably close between the predicted and experimental. The indirect thermosonication method was chosen for extracting guava juice because it achieved the highest increases in juice yield and TSS content. The indirect thermosonication method was also good for extracting pomelo juice as all response variables displayed positive trends as the other two methods presented decrease in AA content. The juice yield obtained via indirect thermosonication, however, had lower juice yield than the control. For extraction of soursop juice, the direct thermosonication method was suitable because it achieved a positive change of AA content as compared with the other two methods. A lower value of juice yield and TSS content increase was acceptable as long as AA content did not degrade, because it is the main nutrient that needs to be preserved in fruit juice production. AA also plays a role as an antioxidant, and it is an unstable compound that can degrade easily under inappropriate conditions [32].

Table 5. Predicted and experimental optimal responses of guava, pomelo, and soursop extraction.

\begin{tabular}{lrrrrrr}
\hline \multirow{2}{*}{$\begin{array}{c}\text { Parameters } \\
\text { Changes (\%) }\end{array}$} & \multicolumn{2}{c}{ Control } & \multicolumn{2}{c}{$\begin{array}{c}\text { Direct } \\
\text { Thermosonication }\end{array}$} & \multicolumn{2}{c}{$\begin{array}{c}\text { Indirect } \\
\text { Thermosonication }\end{array}$} \\
\cline { 2 - 7 } & Predicted & Experiment & Predicted & Experiment & Predicted & Experiment \\
\hline Guava & & & & & & \\
\hline Juice yield & 6.7 & 7.6 & -85.0 & -79.3 & $\mathbf{3 0 . 1}$ & $\mathbf{2 8 . 1}$ \\
AA content & 22.9 & 25.1 & 32.4 & 32.5 & $\mathbf{2 3 . 0}$ & $\mathbf{2 7 . 1}$ \\
TSS content & 25.7 & 26.5 & 26.3 & 25.9 & $\mathbf{2 6 . 8}$ & $\mathbf{2 7 . 4}$ \\
\hline Pomelo & & & & & & \\
\hline Juice yield & 5.8 & 8.7 & 1.3 & 0.6 & $\mathbf{2 . 4}$ & $\mathbf{3 . 7}$ \\
AA content & -2.4 & -3.5 & -1.1 & -2.5 & $\mathbf{0 . 7}$ & $\mathbf{1 . 2}$ \\
TSS content & 1.5 & 1.7 & 2.6 & 2.1 & $\mathbf{2 . 2}$ & $\mathbf{3 . 4}$ \\
\hline Soursop & & & & & & \\
\hline Juice yield & 53.6 & 48.3 & $\mathbf{7 . 2}$ & $\mathbf{9 . 2}$ & 21.0 & $\mathbf{2 0 . 8}$ \\
AA content & -9.5 & -8.8 & $\mathbf{1 2 . 6}$ & $\mathbf{1 4 . 7}$ & -6.7 & -5.1 \\
TSS content & 22.1 & 25.2 & $\mathbf{7 . 8}$ & $\mathbf{7 . 7}$ & 10.9 & 11.5 \\
\hline
\end{tabular}

Bold fonts indicate optimised extraction.

\section{Conclusions}

The blocked face-centred central composite design was suitable for tropical fruit juice extraction optimisation because blocking helps to control the variations of the fruits properties. Based on advantages of extraction time reduction and prevention of AA content loss, ultrasound-assisted extraction methods were found to be helpful in the studies of three difficult-to-extract fruit juices. The best method for guava juice extraction was indirect thermosonication at $1 \mathrm{~kW}$ using distilled water incubated at $55^{\circ} \mathrm{C}$ for $30 \mathrm{~min}$. The indirect thermosonication was also good for extracting pomelo juice at $2.5 \mathrm{~kW}$ with water incubation temperature of $54{ }^{\circ} \mathrm{C}$ for $23 \mathrm{~min}$. Extraction of soursop juice was suitable via direct thermosonication at $10 \%$ amplitude with distilled water at $55^{\circ} \mathrm{C}$ for 2 to $10 \mathrm{~min}$.

Author Contributions: N.A. designed the experiments, collected and analyzed the data, and wrote the manuscript. N.L.C. conceptualized the study, supervised the research, edited, and revised the manuscript. All authors have read and agreed to the published version of the manuscript.

Funding: The study was funded by the Malaysian Ministry of Higher Education's Fundamental Research Grant Scheme with project number 02-10-10-929FR. 
Conflicts of Interest: The authors declare no conflict of interest.

\section{References}

1. Atawodi, S. Nigerian foodstuffs with prostate cancer chemopreventive polyphenols. Infect. Agents Cancer. 2011, 6 (Suppl. 2), S9. [CrossRef]

2. Van Breemen, R.B.; Pajkovic, N. Multitargeted therapy of cancer by lycopene. Cancer Lett. 2008, 269, 339-351. [CrossRef] [PubMed]

3. Worrell, D.B.; Carrington, C.M.S.; Huber, D.J. Growth, maturation and ripening of soursop (Annona muricata L.) fruit. Sci. HorticAmsterdam. 1994, 57, 7-15. [CrossRef]

4. Ko, Y.-M.; Wu, T.-Y.; Wu, Y.-C.; Chang, F.-R.; Guh, J.-Y.; Chuang, L.-Y. Annonacin induces cell cycle-dependent growth arrest and apoptosis in estrogen receptor- $\alpha$-related pathways in MCF-7 cells. J. Ethnopharmacol. 2011, 137, 1283-1290. [CrossRef] [PubMed]

5. Chek Zaini, H.; Zaiton, H.; Zanariah, C.W.; Sakinah, N. High Fiber Cookies Made from Pink Guava (Psidium guajava) Decanter/Agro Waste. 2020. Available online: https://www.doc-developpement-durable.org/file/Arbres-Fruitiers/FICHES_ ARBRES/goyavier_Psidium\%20guajava/High\%20fiber\%20cookies\%20made\%20from\%20pink\%20guava.pdf (accessed on 18 November 2020).

6. Nwokocha, L.M.; Williams, P.A. New starches: Physicochemical properties of sweetsop (Annona squamosa) and soursop (Anonna muricata) starches. Carbohyd Polym. 2009, 78, 462-468. [CrossRef]

7. Economos, C.; Clay, W.D. Food, Nutrition and Agriculture: Nutritional and Health Benefits of Citrus Fruits. 1999. Available online: http:/ / www.fao.org/docrep/x2650T/x2650t03.htm (accessed on 18 November 2020).

8. Tiwari, B.K.; Muthukumarappan, K.; O’Donnell, C.P.; Cullen, P.J. Colour degradation and quality parameters of sonicated orange juice using response surface methodology. LWT Food Sci. Technol. 2008, 41, 1876-1883. [CrossRef]

9. Adekunte, A.; Tiwari, B.K.; Scannell, A.; Cullen, P.J.; O’Donnell, C. Modelling of yeast inactivation in sonicated tomato juice. Int. J. Food Microbiol. 2010, 137, 116-120. [CrossRef] [PubMed]

10. Adekunte, A.O.; Tiwari, B.K.; Cullen, P.J.; Scannell, A.G.M.; O'Donnell, C.P. Effect of sonication on colour, ascorbic acid and yeast inactivation in tomato juice. Food Chem. 2010, 122, 500-507. [CrossRef]

11. Bhat, R.; Kamaruddin, N.S.B.C.; Min-Tze, L.; Karim, A.A. Sonication improves kasturi lime (Citrus microcarpa) juice quality. Ultrason Sonochem. 2011, 18, 1295-1300. [CrossRef]

12. Tiwari, B.K.; O’Donnell, C.P.; Muthukumarappan, K.; Cullen, P.J. Effect of sonication on orange juice quality parameters during storage. Int. J. Food Sci. Tech. 2009, 44, 586-595. [CrossRef]

13. Valero, M.; Recrosio, N.; Saura, D.; Muñoz, N.; Martí, N.; Lizama, V. Effects of ultrasonic treatments in orange juice processing J. Food Eng. 2007, 80, 509-516. [CrossRef]

14. Chemat, F.; Zill, E.H.; Khan, M.K. Applications of ultrasound in food technology: Processing, preservation and extraction. Ultrason Sonochem. 2011, 18, 813-835. [CrossRef] [PubMed]

15. Koshani, R.; Ziaee, E.; Niakousari, M.; Golmakani, M.T. Optimization of thermal and thermosonication treatments on pectin methyl esterase inactivation of sour orange juice (Citrus aurantium). J. Food Process. Preserv. 2014, 39, 567-573. [CrossRef]

16. Tribess, T.B.; Tadini, C.C. Inactivation kinetics of pectin methylesterase in orange juice as a function of $\mathrm{pH}$ and temperature/time process conditions. J. Sci. Food Agric. 2006, 86, 1328-1335. [CrossRef]

17. de Carvalho, J.M.; Maia, G.A.; da Fonseca, A.V.V.; de Sousa, P.H.M.; Rodrigues, S. Effect of processing on physicochemical composition, bioactive compounds and enzymatic activity of yellow mombin (Spondias mombin L.) tropical juice. J. Food Sci. Technol. 2013, 52, 1182-1187. [CrossRef]

18. Wu, J.; Gamage, T.V.; Vilkhu, K.S.; Simons, L.K.; Mawson, R. Effect of thermosonication on quality improvement of tomato juice. Innov. Food Sci. Emerg. Technol. 2008, 9, 86-195. [CrossRef]

19. Terefe, N.S.; Gamage, M.; Vilkhu, K.; Simons, L.; Mawson, R.; Versteeg, C. The kinetics of inactivation of pectin methylesterase and polygalacturonase in tomato juice by thermosonication. Food Chem. 2009, 117, 20-27. [CrossRef]

20. Torres, E.F.; Bayarri, S.; Sampedro, F.; Martinez, A.; Carbonell, J.V. Improvement of the fresh taste intensity of processed clementine juice by separate pasteurization of its serum and pulp. Food Sci. Technol. Int. 2008, 14, 525-529. [CrossRef]

21. Mason, T.J.; Paniwnyk, L.; Lorimer, J.P. The uses of ultrasound in food technology. Ultrason Sonochem. 1996, 3, S253-S260. [CrossRef]

22. Ofori-Boateng, C.; Lee, K. Response surface optimization of ultrasonic-assisted extraction of carotenoids from oil palm (Elaeis guineensis Jacq.) fronds. Food Sci. Nutr. 2013, 1, 209-221. [CrossRef]

23. Sin, H.N.; Yusof, S.; Abdul Hamid, N.S.; Rahman, R. Optimization of hot water extraction for sapodilla juice using response surface methodology. J. Food Eng. 2006, 74, 352-358. [CrossRef]

24. Lee, W.C.; Yusof, S.; Hamid, N.S.A.; Baharin, B.S. Optimizing conditions for hot water extraction of banana juice using response surface methodology (RSM). J. Food Eng. 2006, 75, 473-479. [CrossRef]

25. Cendres, A.; Chemat, F.; Maingonnat, J.F.; Renard, C.M.G.C. An innovative process for extraction of fruit juice using microwave heating. LWT Food Sci. Technol. 2011, 44, 1035-1041. [CrossRef]

26. Chin, L.N.; Tan, C.M.; Pa, N.F.; Yusof, Y.A. Method and Apparatus for High Intensity Ultrasonic Treatment of Baking Materials. U.S. Patent 2013/01894.07 A1, 25 July 2013.

27. Carley, K.M.; Kamneva, N.Y.; Reminga, J. Response Surface Methodology; Technical Report CMU-ISRI-04-136; CASOS: Pittsburgh, PA, USA, 2004.

28. Khuri, A.I.; Mukhopadhyay, S. Response surface methodology. Wires Comput. Stat. 2010, 2, 128-149. [CrossRef]

29. Lenth, R.V. Response-surface methods in R using RSM. J. Stat. Softw. 2009, 32, 1-17. [CrossRef] 
30. Noordin, M.Y.; Venkatesh, V.C.; Sharif, S.; Elting, S.; Abdullah, A. Application of response surface methodology in describing the performance of coated carbide tools when turning AISI 1045 steel. J. Mater. Process Technol. 2004, 145, 46-58. [CrossRef]

31. Cheng, L.H.; Soh, C.Y.; Liew, S.C.; Teh, F.F. Effects of sonication and carbonation on guava juice quality. Food Chem. 2007, 104, 1396-1401. [CrossRef]

32. Burdurlu, H.S.; Koca, N.; Karadeniz, F. Degradation of vitamin C in citrus juice concentrates during storage. J. Food Eng. 2006, 74, 211-216. [CrossRef]

33. Trappey, A.F.; Johnson, C.E.; Wilson, P.W. Characterization of juice extraction methods utilizing fresh mayhaw (Crataegus opaca Hook.) fruit. Int. J. Fruit Sci. 2008, 8, 318-331. [CrossRef] 